\title{
Hungarian Consequences of the Toleration Missions to Bohemia and Moravia around $1800^{1}$
}

\author{
JÁNOS UGRAI
}

\section{Introduction}

It is a well known fact to Hungarian and Czech historians that after Joseph II's Edict of Toleration of 1781 the Protestants in Hungary and in the Bohemian lands established a fruitful reciprocal collaboration. In the early days, most of the new pastors were Hungarians who came within the frameworks of the „Bohemian mission“: mostly Hungarian early-career pastors rushed to support the revival of the suffering Bohemian and Moravian Reformed communities. ${ }^{2}$ After the turn of the century, this strategy was abandoned and instead, Bohemian-Moravian students came to study at the Hungarian Reformed Colleges. In this way, this cross-border relationship between Central and Eastern Europe was preserved for decades and has permanently shaped the identity of Calvinists in both countries until now.

Whereas the missionary work of the Hungarian pastors in Bohemia and Moravia has been amply researched, ${ }^{3}$ the impact of their missions on Hungary has been largely

1 The study originated within the framework of the project Grantová agentura České republiky 18-00885S - Zrozeni z osvicenských reforem. Integrace skupiny tolerančnich kazateli z Uher v procesu formování české společnosti (1781-1870) [2018-2020] and NKFI FK 132451 - A professzionalizáció története Magyarországon a 19-20 században európai kontextusban - A History of Professionalization in Hungary in the Context of 19th-20th-century Europe.

2 Based on autobiographical memories Richard Pražák published a large study on the topic in Hungarian. Richard PRAžÁк, A református magyar értelmiség Cseb-és Morvaországban a cseh nemzeti megujjhodás kezdetén [Reformed Hungarian Intellectuals in Bohemia and Moravia at the Beginning of the Czech National Revival], Századok 98, 1964, pp. 3-41; IDEM, Die kulturell aufklärende Tätigkeit der madjarischen reformierten Intelligenz in der Zeit der tschechischen nationalen Wiedergeburt, Sborník prací Filozofické fakulty brněnské univerzity, Řada historická (C) 13, 1964, pp. 127-146. Ferdinand Hrejsa, Jan Végh. K 150 - letému výroči tolerance, Praha 1930 was reedited in 2002 in a Hungarian translation as Ferdinand Hrejsa, A csehek magyar apostola. Végh János élete (1755-1830) [The Hungarian Apostle of Bohemians: The Life of János Végh (1755-1830)], Debrecen 2002; Eva MeLmuкová-ŠAšEcí (ed.), Evangelíci v rané tolerančni době v Čechách a na Moravě, Neratovice 2017. Recently on the topic in Czech, with detailed Bibliography Sixtus Bolom-Kotari, Tolerančni kazatelé z Uher v procesu formování české společnosti (1781-1870), Český časopis historický 117, 2019, pp. 318-346; IDEM, Promèny společenskébo postaveni uherských tolerančníh pastorũ v Čechách a na Moravè v obdobi kolem roku 1800 [Transformations of Social Status of Hungarian Toleration Preachers in Bohemia and Moravia around 1800], Studia historica Nitriensia 24, 2020, pp. 93-110.

3 Gabriela Krejčová Zavadilová - Hana SToKLAsová, Evangeličtí kazatelé z Uher - formování nové společenské skupiny, Cornova 6, 2016, pp. 35-60; Gabriela Krejčová Zavadilová, Nástin vývoje 
neglected. Their mission was, however, a relationship with two ends. Due to the various difficulties of research methods, it has yet been unknown exactly who studied at Hungarian reformed colleges and for how long. In what follows I seek to close this gap on the basis of recently collected data on students of the Reformed College of Sárospatak and the documents on the repatriation of Toleration Preachers and their widows.

It has been also largely forgotten that many of those who had carried out the „Bohemian mission" and provided pastoral services for a Bohemian or Moravian congregation eventually returned home after a while. Either in active service or as elderly preachers, they asked the Church to support their repatriation to Hungary. In their efforts to justify their return, many of them provided reports on the circumstances in Bohemia and Moravia and thereby provided important information on how they fared, as well as on the internal relationships inside the communities at the place of their assignment. The welfare support provided to these mostly young pastors for decades reveals a lot about the state of the Church in Hungary. The present study discusses the phenomenon through the example of pastors who started and finished their missions in the Reformed Church District of Tiszáninnen (the northern Tisza region).

The choice of the Reformed College of Sárospatak and the Reformed Church District of Tiszáninnen is not a coincidence: both insitutions took the lion's share of work in the Bohemian mission. Even though we cannot argue that Bohemian and Moravian congregations had no contact with other reformed church districts in Hungary, the rate of contact with Sárospatak and Tiszáninnen may be estimated at 90 percent.

\section{The Reformed College of Sárospatak and the Reformed Church District of Tiszáninnen in the Bohemian Mission}

The College of Sárospatak was the second largest Reformed college in Hungary in the first half of the 19th century. ${ }^{4}$ The number of students of the college fluctuated between 960-1670, most often in the range from 1100 to 1200 . Students of elementary schools,

počtu obyvatel a členu evangelického sboru h.v. v Moravči v době tolerančni 1783-1874, Jihočeský sborník historický 87, 2018, pp. 227-242. The latest volume in publication is Sixtus Bolom-KotaRi - Gabriela Krejčová Zavadilová - Michal Severa - Andor MÉszáros (edd.), Zrozeni z osvicenských reforem: Integrace skupiny tolerančnich kazatelü $z$ Uher v procesu formováni české společnosti (1781-1870) (to be published).

4 In 1790 the Reformed people made up $16 \%$ of the population, $55 \%$ of the Hungarian population was Roman Catholic, about 7 \% Greek Catholic, $11 \%$ Greek Orthodox, and 9.3\% Lutheran. See Margit BALOGH - Jenő Gergely, Egyházak az újkori Magyarországon [Churches in Modern Hungary], Budapest 1992,p. 149. The College of Sárospatak was also one of the largest institutions in the country as other denominations typically maintained more fragmented schools focusing on a specific age group or task. Dávid Csorba, The Educational Model of the Calvinist Colleges, Hungarian Educational Research Journal 7,2017,pp. 114-127; Péter KóNYA, Konfesionálne školy v (niektorých) zemplininskych a užkých zemepanských mestách v 17.-19. storoči [Confessional schools in (some) Zemplén and Ugh landowner's towns in the 17th-19th centuries], Historia Ecclesiastica 11, 2020, Nr. 2, pp. 79-97. 
grammar schools and the academy attended courses within the institution's walls. The proportion of elementary school students was generally 5-6\%, that of the grammar school students $55-70 \%$, and that of academy students 30-40\%. At the Academy the „Togats“ (the ones wearing a cassock) and the „Non-Togats“ (the ones not wearing a cassock) studied separately. The latter pursued legal studies and did not prepare for careers in church. Typically three to four times as many Togats studied at the college than Nontogats.

The large college stood out in Sárospatak, since the entire population of the town was merely three times as large as the number of students at the college. Besides, the college was an alien entity in its surroundings: Whereas the region was sinking into poverty, deprivation and lagging behind in the process of embourgeoisement, the college was gaining national significance in many disciplines. The introduction of new subjects, the modernization of legal education and the the spread of education in Hungarian were a series of innovations at the Reformed College of Sárospatak which made it outstanding not only in its immediate environment but in the national context as well. It is important to stress that the first such instance of prominence occured in the mid-1 $7^{\text {th }}$ century and has a direct link to Bohemia and Moravia, since it was connected to the brief period Jan Amos Comenius worked in Sárospatak (1650-1656). The Bohemian and Moravian students coming to Sárospatak after the Edict of Toleration could witness the prime of the institution. Apparently, as a result of the Curricular Reform of 1796, the syllabus was modernized in a way that was unparalelled in Hungary. This was ensured by the introduction of disciplines that could be applied in civic life (science, statistics, politics, pedagogy, agronomy, etc.) and the spirit of intellectual freedom. ${ }^{5}$

The Reformed Church District of Tiszáninnen played a leading role in the revival of Bohemian and Moravian Reformed congregations. Despite the initial organizational difficulties and the reluctance of students speaking good Slovak to move abroad, in November 1782 seven young men set off from Sárospatak, and another 34 left the region by $1787 .{ }^{6}$ Most of them had only just graduated from the Reformed College of Sárospatak and, apart from a few exceptions, they all instantly became pastors. (We only know of three or four young men who went to work as schoolteachers in a Bohemian or Moravian congregation.) The emigration reached its peak in 1783, when, from the Reformed Church District of Tiszáninnen alone, 30 young preachers found a new home. This marked the end of targeted emigration of Hungarian pastors; after that the group of repatriated pastors were joined by newcomers only in some specific cases. The Reformed Church District of Tiszáninnen and the largest Hungarian Calvinist College in Debrecen also actively participated in the „Bohemian mission.“ From the latter,

On the history of the college see Dénes Dienes - János Ugrai, History of the Reformed Church College in Sárospatak, Sárospatak 2013.

6 F. Hrejsa, A csehek, pp. 34-40. 
however, only 9 young men moved abroad to help and to start a new life, while only one pastor from Transylvania participated. ${ }^{7}$

The mission was a significant event not only in the life of Bohemian and Moravian congregations but also in the development of the Reformed Church District of Tiszáninnen. The reasons for this are specific, historical and characteristic solely of the North-eastern region of Hungary. The Reformed Church District of Tiszáninnen was established quite late - the uniform superintendence started in 1735. Before then, dioceses were the largest units of church administration in the region, which was in compliance with the Reformation conditions. The deans (seniors) were proverbially as „powerful as bishops“ in their own dioceses. ${ }^{8}$ Organized upon order by the Habsburg administration, the superintendence remained rather weak for decades to come and the deans continued trying to preserve their former influence. ${ }^{9}$ The superintendent Sámuel Szalay was only able to considerably change this decentralized power structure (actually, one that often displayed anarchic characteristics, too) with the help of the „Bohemian mission."With the freedom granted by the Edict of Toleration and the end of the Counter-Reformation, this was the first task that Szalay took on as the leader. He organized a campaign that could prove the legitimacy of church district administrations. Furthermore, by showing more dedication and achieving more success than Debrecen and the Transdanubian region, he could strengthen this legitimacy not only in North-eastern Hungary but at the national level as well.

Although Sámuel Szalay's determination was based on personal conviction, his role in the „Bohemian mission“ cannot be regarded as a profoundly voluntary commitment. In the few years prior to the Edict of Toleration, Bohemians deported due to their religion found their new home in the Zemplén region, which was Szalay's bailiwick. The Bohemian Calvinists who were settled in the village of Kak put considerable pressure on Szalay and turned him into a decided supporter of the cause within a few months. ${ }^{10}$ The velocity and success of the campaign really increased Szalay's prestige. (Let us remember that half of the approximately 70 Bohemian and Moravian Calvinist congregations could only be revived and reorganized with an immediate help from the Reformed Church District of Tiszáninnen.)

7 R. PražÁK, A református 1964, pp. 10-13.

8 Dénes Dienes, $A z$ elsö püspökválasztás a tiszáninneni református egyházkerületben [The First Appointment of Bishops in the Reformed Church District of Tiszáninnen], in: Csaba Fazekas (ed.), Fiatal egybáztörténészek irásai. [Studies by Young Church Historians], Miskolc 1999, pp. 63-75.

9 Gábor Ôri Fülep, superintendent in the Reformed Church District of Tiszáninnen at around the 1800s wrote surprisingly honestly about the phenomenon. János UGRAI, $A$ Tiszáninneni Református Egyházkerület elsós szuperintendensei. Öri Fülep Gábor feljegyzései [The first Superintendents of the Reformed Church District of Tiszáninnen. Notes of Gábor Ori Fülep], Historia ecclesiastica 11, 2020, pp. 235-255.

10 R. PražÁk, A református, pp. 13-17. 


\section{Bohemian and Moravian Students at Sárospatak}

Compiling a list of names of the students at the Reformed College of Sárospatak is a complicated task that may begin with reviewing and comparing two more or less complete sources. The students who attended the pastoral training at the College (who had already finished grammar school) were registered at the time of the enrolment from 1797. Personal data were not recorded in the same way from year to year. However, we have at least a relatively complete list of students appearing in the pastoral training program and signing school laws. ${ }^{11}$ In principle, students who left the ministerial training program were also registered - in fact, much earlier, starting the report book in $1783 .{ }^{12}$ On the one hand, we can almost never encounter personal data in this list: apart from the name of the person, only the date of leaving and the destination are recorded. On the other hand, the registrars were demonstrably inconsistent: at times, only those who took on teacher's or chaplain's responsibilities were registered, and thus they had important positions in the Church. However, at other times, other reasons (going on to study elsewhere, taking on a civil occupation, illness, death, etc.) were also indicated - but it is difficult to say when and who considered their description important or ignorable. In this way, the leave book may only be used to determine when students completed their studies in Sárospatak.

In addition, the Sárospatak College Archives preserve many lists of students. These can be divided into two groups in terms of the task: there are exam and absenteeism records, and lists of students signing up for a professor's course, which by their character contain only a fraction of the names of college students. (In addition, they usually contain no other name besides the first name, so they are not very helpful if you wish to identify a person.) In addition, there are so-called "generalis tabellas", which were supposed to list all the students of the elementary school, the grammar school and the academic classes per school year (or more exactly semester). In theory, these student lists contain a great amount of personal information (father/patron's name; place of residence; religion; age; social and school position; marks). Unfortunately, however, the state of the "generalis tabellas" presents complex problems. On the one hand, they are often as brief as an exam grade sheet, i.e. they often contain solely a list of first names. On the other hand, we are sometimes confronted with an infinite amount of duplicates with varying degrees of content. Finally, there are no reliable and complete lists of names for entire school years. ${ }^{13}$

11 Protocollum Togatorum subscribentium ad anno 1797, Tiszáninneni Egyházkerület Levéltára (TREKL) K. e. I. 1.; Az iskolai törvényeknek aláirottak nevei 1841-ik évtól, TREKL K. e. I. 4. The list of names is to be published in a separate volume in 2021.

12 János UGraI, A Sárospataki Református Kollégiumból távozó tógátusdiákok, 1781-1873 ["Togat“students leaving the Sárospatak Reformed College, 1781-1873], Sárospatak-Tiszaújváros 2012. Online as www.patakarchiv.hu/wa_files/diaknevsor_patak.pdf (accessed on 30/03/2021).

13 I have been researching the history of the College of Sárospatak for 20 years and have repeatedly analyzed the available students' name lists very thoroughly. I have never discovered the internal logic 
As a result, to the best of our present knowledge, it is not possible to accurately determine the number and composition of college students for each year during the mid-1850s. It is also very difficult to follow the studies of a group of students, and similarly, at the individual level, it is easy to lose sight of those whose college life we are interested in. This is the reason why we believe that someone (or some persons) from Bohemia and Moravia may have studied in Sárospatak despite the fact that their names do not appear in the information below.

First, we recorded the Bohemian and Moravian students found in the enrolment register. Subsequently, we systematically revised the "generalis tabellas" that were found and appeared to be reliable. With this procedure, we sought to expand the repository and, thus, we managed to reconstruct the study paths of some students for several academic years. We usually recorded the personal data (place of residence, patron's name, social position) entered at the time of „subscriptio“, i.e. enrolment, and we clarified, corrected it with the help of the entries found for certain academic years and possibly supplemented it with another version. Finally, in the few cases where we knew it, we close the data set with the relevant details of the leave book, i.e. when the person leaves Sárospatak.

\section{The results within the context of Sárospatak}

The procedure can help to prove the presence of some 60 Bohemian and Moravian students at Sárospatak. ${ }^{14}$ Non-Protestant students (Greek Orthodox, and a small number of Jews) were to be found exclusively among the Nontogats at the college. But only the presence of Lutherans from Szepesség (in north-eastern Slovakia) can be said to be more or less continuous, but in reality the student society was extremely homogeneous in both ethnic and religious terms.

The presence of nearly 60 Bohemian and Moravian students can be evaluated in the light of this: in an almost completely closed institution, attended mostly by Hungarian

of the source file, or met en expert who could help me with this. A team headed by László Szögi is currently conducting an extensive research in Hungary with the aim of publishing a database of Hungarian university and academy students in a similar system. So far, 20 volumes have been published, each providing the list of students' names at a major educational institution (academy, Protestant college). According to László Szögi, the volume on the students of the Reformed College of Sárospatak is unlikely to be published in near future, due to the above mentioned difficulties with the sources. For more on the theoretical assumptions of the project in German see László Szögr, Die Ergebnisse und Aufgaben des Schreibens über die ungarische Universitätsgeschichte, in: Ágnes Fischer-Dárdai - István Lengvári - Éva Schmelczer-Pohánka (edd.), University and Universality. The Place and Role of the University of Pécs in Europe from the Middle Ages to Present Day, Pécs 2017, pp. 33-46.

14 See Appendix of this study. The present study only includes the students name list, their first and last traces at Sárospatak. More detailed data and precise archival notes shall be published in a Czech-language study, currently which is under in publication: S. Bolom-Kotari - G. Krejčová Zavadilová - M. Severa - A. MÉszáros (edd.), Zrozeni z osvícenských reforem. 
Calvinists, the Bohemian-Moravian students of some sorts were, in fact, always present. What is more, they were present for long periods of time, since most of them were studying at the college for years. In this way, they must have had an intense relationship with their fellow students and other students. This certainly had an impact on the students' socialization and communication with the outside world, with "strangers“ at the Reformed College of Sárospatak, which was otherwise inclined to seclude itself in regional and cultural terms. ${ }^{15}$

Most of the students are on the list of the Togats, so they completed certain years of pastoral training in Sárospatak. (It was not unusual for Hungarian students not to accomplish all eight or nine years of the pastoral training academy, because they would graduate much earlier, even as $4^{\text {th }}-5^{\text {th }}$ year students. This was enough to obtain a teaching position. When there were not enough pastors, one could receive a pastor assignment even after a short period of study.) It is striking that in several cases (e.g. Károly Fleischer, János Kazay, Ferenc Kral, Mihály Marton, Antal Perklich, Ferenc Serák, István Tardy, Ferenc Vidrál), those concerned spent years in the grammar school prior to the academy. In addition, many of them (Kral, Perklich, Serák, Vidral) most likely did not have Hungarian ancestors at all.

In several places on the list, the rank of respective students in the peers' hierarchy were indicated. This ranking was based on academic achievements, but certain disciplinary offenses could also result in the student's degradation, i.e., lowering his ranking. From the data revealed so far, it seems that students from Bohemia and Moravia were not excluded from relatively high positions. Although the language difficulties (in Sárospatak the Hungarian language was widely used as the language of instruction in the grammar school from 1797 and at the academy from 1818), and the unequal pre-studies ranked most students in the middle or even worse position. At the same time, they were not excluded from rising in the hierarchy, or from being particularly good, or from becoming a leader in the particular study group (György Fazekas, József Fleischer, Josephus Hohneh, István Tardy, József Toronyay and József Végh). It is also true, however, that it was possible mainly for students who had Hungarian parents to achieve outstanding educational results.

That is why the case of Mathaeus Kubesch and Joannes Schollin is interesting. The only thing we know about the latter so far is that he spent his ninth academic year in Sárospatak, it was an exceptional option that was given only to very few highly talented students each year. For the time being, we do not have much data on how well

15 We assume a similar effect in connection with the Bohemian-Moravian Reformed Churches roughly on the same scale, the presence of Lutheran German students of Szepesség, who regularly appear in Sárospatak. János UgraI, Iskola a ,határokon". A Sárospataki Református Kollégium idegen nemzetiségü és felekezetü diákjai 1777-1848 között [A School on the „Border": Students from Different Nationalities and Denominations at the Reformed College of Sárospatak], in: Gábor Egry - István Feitl (edd.), A Kárpát-medence népeinek együttélése a 19-20. században [The Coexistance of Peoples of the Carpathian Basin], Budapest 2005, pp. 16-18. 
Kubesch was doing in Sárospatak. What is noteworthy, however, is that one year we find him among the iurates (law clerks), and the next year he became a contrascriba (checking-clerk). Both required the votes of „Togat" students, and both meant important student functions. A contrascriba was certainly the second most important student function at a time when student council officials still exercised considerable economic and disciplinary authority at the College of Sárospatak. Winning such a function through the votes of fellow students meant that Mathaeus Kubesch was a central, recognized figure in school student life for years.

\section{Various forms of returning from Bohemia}

In fact, the reversed direction of the Bohemian mission started earlier than the first students began their studies at Sárospatak. Less than a decade after the mission started, the pastors wishing to repatriate appeared, all reporting on the hardships and miserable living conditions in Bohemia.

There were several different ways of repatriation and thus many different versions of the same problem, occurring almost simultaneously. The church leaders in Hungary were faced with cases that may be divided into three groups: those in need of financial aids, those wishing to find employment, and those who sent their sons to be educated at Sárospatak but did not intend to repatriate. These requests, albeit requiring a lot of organization and a huge effort, could hardly be denied, for two reasons. Firstly, the repatriates who were willing to undertake the Bohemian mission were recruited and actively supported by the superintendent. Secondly, the ambition of the late Sámuel Szalay did strengthen their close relationship with the Reformed Church District of Tiszáninnen and thus facilitated its survival. Back in Szalay's time there were, in fact, plans to bring the Bohemian and Moravian congregations, reorganized with Hungarian help, under control by the superintendent of Tiszáninnen to form one church district. Eventually, these plans were not realized, and the Bohemian and Moravian congregations organised their own autonomous superintendences. However, the issue remained on the agenda for quite a while and could strengthen the Hungarian pastors' loyalty towards their home country and their ties to their original church district.

As mentioned above, many became unfit for duty due to ill health or old age. In other cases, their death could cause their close relatives to ask for help. Since most of the Bohemian and Moravian congregations and their two superintendecies were not even as wealthy the Hungarian congregations of the Reformed Church District of Tiszáninnen, many pastors decided to move back home. The first person to ask for help was Mihály Vitzentz's widow, Klára Szalay in $1795 .{ }^{16}$ Three years later she asked again for some compassion, as she had received no reply for her request. This time she stressed that her husband served for nine years under the most difficult conditions without complaining.

16 TREKL, A. XXV. 9319. 
His faithful service ended with his death, and although his widow worked night and day and brought up four children, they could hardly get by on their own. ${ }^{17}$ We may tell from this remark in her letter that Vitzentz's widow was in need of some kind of financial help from the church district between 1791 and 1792. However, it would have to be a case-by-case aid which was thus highly uncertain and impossible to plan on.

The fate of Ferenc Kováts former superintendent in Bohemia was quite similar: he was among the first pastor to undertake the mission, and he even went back from Hungary to Moravia once, believing that God needed his service more in the latter. As a superintendent and later a member of the consistory of Vienna, he gained both influence and wealth, but since he had to travel a lot, his expenses were quite high. ${ }^{18}$ After a stroke he was unable to work and in 1798 he lived in great poverty with his wife and three children. ${ }^{19}$ In recognition of his former significant role, Kováts received considerable support: in 1799 the district granted him an annual subsidy of $30 \mathrm{Ft}^{20}{ }^{20}$ Meanwhile, Kováts was trying to help his son-in-law, András Szeghő (likewise serving in Bohemia) get a position in Tornagörgő - but this shall be discussed later.

The above-mentioned requests were made before the establishment of the deficiens cassa and thus led to conflicts among the dioceses of the Reformed Church District of Tiszáninnen. The Upper Borsod County Diocese, for instance, indicated in 1800 that their congregations supported the widows and orphans of the Bohemian-Moravian pastors, as well as the Bohemian and Moravian young men studying in the diocese every year but they wished to share the costs with the other dioceses from that year on, especially because they were not closer relatives to the Bohemians than the others. ${ }^{21}$ The establishment of the deficiens cassa did not bring about a radical change in itself, as these funds were separate at the level of the dioceses, whereas the compensations were occasional and depended on fundraisers and other unpredictable payments. ${ }^{22}$

Although the system of the deficiens cassa was unsuitable for making regular pension-like payments, it does provide a great opportunity for research on who were still alive among the destitute repatriates in the 1820s and 1830s. The list of disabled preachers is relatively easy to reconstruct from the archives from the mid-1820s on (from around 1826-1827). At that time only five former Bohemian-Moravian pastors or widows received aids. It is thus certain that financial support was given to Joel Jessenius's widow,

17 TREKL, A. XXVII. 9987.

18 On another Superintendent see Sixtus Bolom-Kotari, Svoboda svèdomi. Superintendent Michael Blažek a protestantská společnost pozdního osvicenství, Praha 2016.

19 TREKL, A. XXVII. 9859.

20 TREKL, B-28. 459/39.

21 TREKL, A. XXVIII. 10.699.

22 János Ugrai, History of the Reformed District Tiszáninnen. From Edict of Toleration to 1859, Sárospatak 2017, pp. 64-66. 
who spent her last years in Abaúj County (and received 4-8 Ft between 1827 and 1831), as well as to Sámuel Kaposy and later to his widow. (Sámuel Kaposy's name is mentioned regularly between 1827 and 1838, with an aid of 14-30 Ft from the diocese. It is also known that he went entirely blind towards the end of his life. His widow got an annual aid of 5-7 Ft until 1842. Both lived in the village Magyarbőd in Abaúj County.) János Sallai's and András Szeghő's widows each appear on the list once, in 1827 and in 1831, respectively. Both widows received financial support of about $10 \mathrm{Ft}$. It is also known that István Gaál was granted financial aid by the Upper-Zemplén County diocese three times between 1827 and 1832 - first rather generous sums, 30 and $40 \mathrm{Ft}$, then eventually $9 \mathrm{Ft}$.

Unfortunately, there are few data available about beneficiaries of the deficiens cassa in the previous years. Beneficiaries were not listed consistently prior to that period (or, if they were, these data have not been discovered yet). However, the documents and reports that have survived from the 1820s reveal that repatriates unfit for duty appeared in Hungary as early as the first decade after the „Bohemian mission“ and taking care of them provided a lifetime of duties for the heads of the Reformed Church District of Tiszáninnen.

\section{Returning to the pulpit - the repatriation of active pastors}

Another large group of repatriates consisted of pastors who remained active even for decades but wished to move back home from Bohemia and Moravia. Their decision was motivated by the adverse conditions they encountered there. Their complaints were not only related to the poverty experienced in the Bohemian and Moravian regions. In the early years of the mission it was generally feared that the fate of the young pastors in these foreign lands would be extreme poverty. In merely 10 years this fear proved to be completely wrong. Initially, György Fazekas, former preacher of Lečice, was the only one who asked the church district in 1790 to be allowed to continue his career in Hungary, due to poverty and personal misery. He wished to work in a more peaceful place after what he referred to as indescribable privation. ${ }^{23}$

At the same time, many considered the social conditions they found as alien and repulsive, and therefore wished to return home. The relationship between religious groups is perhaps the most striking negative aspects mentioned. For example, in connection with his son-in-law's intentions of repatriation, Ferenc Kováts reported on the dangers of religious feuds: András Szeghő wished to return from Bošin because the superstitious Catholics had accused him of setting a barn on fire, so he could not stay there for much longer - it was only God's mercy that had saved him from the angry crowd thus far. Sámuel Szűcs, another preacher who later became superintendent, requested permission to repatriate after „having been in hiding, away from my home country for 15 years. “24

23 TREKL, A. XXIV. 8763.

24 TREKL, A. XXVII. 9870. 
In 1799 Imre Csider wrote a letter from Lečice, Bohemia. Although he did not grow tired of the immense burden, he had been enduring patiently for 17 years, he wished to provide for his three children. His 13-year-old daughter would soon reach a marriageable age but in Bohemia he could only find peasants to marry her off to, as prospective grooms who had plots of lands asked for an ,audaciously“ large dowry, 900-1000 Ft. Furthermore, he intended to have his 8-year-old son educated, obviously in Hungary. What Csider found even more exasperating was the „irresolute religiousness" of the people: a believer of the Reformed Church could easily convert to Catholicism overnight he claimed. For all these reasons, Csider asked for a better post somewhere in Hungary, in return for his devoted service and the hardships he endured. ${ }^{25}$ At roughly the same time, János Thuróczy also wished to return. The pastor of Krabčice pointed out his son's education as his main reason. His name, however, is not featured among the data on pastors, so we have no knowledge of what happened to him later. ${ }^{26}$

János Sallai repatriated after 21 years of service and got a job as a pastor in the diocese of Makkoshotyka (Zemplén County). A year later, however, he asked for financial aid from the deficiens cassa - that is, for permission to retire - on the basis of feebleness and poverty. Two years later, in 1807 - when he lived in Kenézlő in Zemplén County - , he reported having neither clothes, nor food. ${ }^{27}$

Sámuel Galambos's letter is highly interesting. Galambos became preacher of the Soběhrdy congregation in 1783, and in 1810 he wrote a letter on behalf of the others in which he complained about their poverty and asked for help. ${ }^{28} \mathrm{He}$ stressed his destitution again in another letter a year later, but also mentioned that many of his former fellow pastors in Bohemia got good jobs: György Fazekas moved to Lak and Albert Baranyai could relocate to Tomor, while Galambos himself had to live in poverty in Sajókazinc. ${ }^{29}$ Galambos's destitution became permanent and in the following years he regularly had to beg for alms. ${ }^{30}$ The problem got worse because his Catholic-born Bohemian wife had a long-term illness. His condition could finally be aleviated when he was employed in Rudabánya in 1811. Nonetheless, as soon as his financial position improved, he immediately found himself in the centre of conflicts. A couple of years later he had to report hostility towards him, besides claiming to his superior that there had never been a year when he received all his wages. ${ }^{31}$

25 TREKL, A. XXVIII. 10.322.

26 TREKL, A. XXVIII. 10.323.

27 TREKL, A. XXXI. 11.989; A. XXXIII. 12.597-598. 1811. évi hasonló panasza: A. XXXV. 13.868.

28 TREKL, A. XXXV. 13.595.

29 TREKL, A. XXXV. 13.758.

30 TREKL, A. XXXV. 13.911.

31 TREKL, A. XL. 16.352. 
All in all, merely 11 of the 38 pastors that had moved to Bohemia and Moravia can be found in the database of pastors of the Reformed Church District of Tiszáninnen in the early $19^{\text {th }}$ century. ${ }^{32}$ Identical names may further complicate the picture and perhaps the number of pastors who had truly been to Bohemia and Moravia is a little lower. This would mean that every fourth preacher repatriated to Hungary and got a job.

\section{Table 1 - Repatriate pastors taking up posts}

\section{in the Reformed Church District of Tiszáninnen}

\begin{tabular}{|c|c|c|}
\hline Name & $\begin{array}{l}\text { First place of assign- } \\
\text { ment in Bohemia/ } \\
\text { Moravia }\end{array}$ & $\begin{array}{l}\text { Places of assignment in the Reformed Church } \\
\text { District of Tiszáninnen, Hungary }\end{array}$ \\
\hline István Bereti & 1784: Velenice & $\begin{array}{l}\text { 1798-1802: Hejőszalonta (Borsod) }-1 \\
\text { 1803-1805?: Sajóecseg (Borsod) - } 4 \\
\text { 1803?-1806†: Kistokaj (Borsod) - } 4\end{array}$ \\
\hline István Breznai & 1782: Javorník & 1778-1814: Gálszécs (Zemplén) - 7, 10, 8 \\
\hline Imre Csider & 1783: Semtěš & 1800-1815: Zádorfalva (Gömör) - 8, 4, 7 \\
\hline György Fazekas & 1784: Ledčice & $\begin{array}{l}\text { 1792-1794: Onga (Abaúj) - 5 } \\
\text { 1811-1813: Lak (Borsod) - } 5 \\
\text { 1813-1819: Izsófalva (Borsod) }-4,7\end{array}$ \\
\hline István Gaál & 1783: Telecí & 1821-1822: Bodzásújlak (Zemplén) - 4 \\
\hline Sámuel Galambos & 1783: Soběhrdy & 1812-1838: Rudabánya (Borsod) - 3, 3, 4, 5, 6, 3 \\
\hline Sámuel Kapossy & 1783: Nebužely & 1801-1807: Gortvakisfalud (Gömör) - 2, 5 \\
\hline János Sallai & 1783: Dvakačovice & $\begin{array}{l}\text { 1805-1807: Makkoshotyka (Zemplén) - } 2 \\
\text { 1807-1821: Kenézlő (Zemplén) - 1, 2, 2,1 }\end{array}$ \\
\hline András Szeghő & 1783: Krakovany & $\begin{array}{l}\text { 1800-1805: Harsány (Borsod) - } 4 \\
\text { 1805-1807: Tiszaszederkény (Borsod) }-4 \\
\text { 1807-1830: Nemesbikk (Borsod) -4, 6, 4, 4, 3, } 4\end{array}$ \\
\hline István Szeremlei & 1783: Velim & 1831-1835: Martonyi (Borsod) - 4 \\
\hline Sámuel Szúcs & 1783: Černá & 1810-1813: Rásonysáp (Abaúj) - 5 \\
\hline
\end{tabular}

I use a rather complicated method to determine how powerful the congregations of the Reformed Church District of Tiszáninnen were in the first half of the $19^{\text {th }}$ century and how much they could attract or keep preachers there. I rank the congregations on the basis of an 11-point scale I have developed. It is divided into periods of five years. The essence of the method is to consider not only the pastors' salary, but also the willingness of the members of the congregation to donate, especially for purposes independent

32 János Ugrai, A Tiszáninneni Református Egyházkerület lelkészei. Adattár [Pastors of the Reformed Church District of Tiszáninnen: A Database], Sárospatak-Tiszaújváros 2017; http://patakarchiv.hu/ portal/e-konyvtar/adattar (15.3.2021). 
of the congregation (e. g. paying the Protestant agent in Vienna). ${ }^{33}$ The pastors' salary cannot be used for comparison in a database aiming to be exhaustive because it included a high rate of allowances in kind. There are even more disturbing factors, such as the ratio of denominations in a settlement, its geographical attributes or the social composition of the congregation. All these factors may have a substantial bearing on the „appeal“ of a congregation.

In the table above, the numbers standing next to the names of Hungarian congregations indicate their rank in the given 5-year term. In case the pastors' place of assignment remained to same for more 5-year terms, several ranks are indicated. This may provide a more complex picture of whether a pastor remaining in the same place for a longer period could strengthen the relationship of the members and the congregation, and effectively increase the congregation's appeal to keep the pastor.

The results suggest that the pastors repatriating from Bohemia and Moravia were never given a position in a prestigious congregation (ranks 9 to 11), and only a few were employed in a congregation at a lower level (ranks 6-8): István Breznai immediately found a suitable environment in Gálszécs in Zemplén County and Imre Csider in Zádorfalva in Gömör where they could be satisfied after their „mission“ abroad. The rest of the repatriates are distributed almost evenly between very weak (ranks 1-2) or average (ranks 3-5) congregations. Those repatriated pastors who could spend longer time in one place could rarely induce the members of the congregations to donate more: only Breznai and Sámuel Galambos in Rudabánya proved to be successful in this respect.

Based on these indicators it is clear to see that those repatriating as active preachers ended up among the lower or middle third of Reformed preachers in the North-eastern Hungarian region. None of them became reputed pastors during their career in Hungary. Nor can we find any examples of repatriates appointed to top positions (e.g. deans) at the level of the diocese of the church district.

\section{Summary}

Help provided by fellow believers from Hungary played a crucial role in the revival of Protestantism in Bohemia and Moravia after the Edict of Toleration. Two thirds of the approximately 70 reorganized Reformed congregations had Hungarian pastors from Hungary. The majority of these pastors were sent by the Reformed Church District of Tiszáninnen, which convinced almost 40, mainly early-career young preachers to participate in the „Bohemian mission.“

33 The method and the ranks of the database have been used before in two short studies published in Hungarian, so the first problems have already been eliminated. The data published in the present paper seem reliable. The method was briefly described in Hungarian in János UGRAI, Iskolai mobilitás és társadalmi emelkedésA sárospataki példa a 19. század elsö felében [Educational Successes and Social Advancements: The Example of the Reformed College of Sarrospatak in the First Half of the 19th century], Századok 154, 2020, pp. 73-76. 
More than one decade after the peak period of patriation in 1782-1784, new forms of the Bohemian mission appeared at Sárospatak. On one hand, the Reformed College of Sárospatak admitted Bohemian and Moravian students, predominantly taking part in ministerial training. Despite the difficulties encountered, data about some 60 students could be uncovered from the school registers of Sárospatak. Among them, there are students with no Hungarian ancestors, and students who could get major positions at the college and presumably excelled in their studies. The continuous presence of Bohemian and Moravian students at the almost entirely homogenous reformed college was a striking phenomenon in the first third of the $19^{\text {th }}$ century.

The other important result of the mission was repatriation. About a half of the pastors who emigrated between 1782 and 1784 repatriated to the Reformed Church District of Tiszáninnen in the following decades. One group of the repatriates was in need of immediate help due to ill health or old age, or after their death the repatriation of their widows and orphans had to be arranged. Another group - one fourth of participants in the mission - continued their career in the North-eastern Hungarian region. None of them were placed in wealthy or strong congregations, nor did they receive major positions in the church. After temporary employment problems, they would continue their careers in Hungary in average or even weaker congregations.

Such a distribution of pastors further intensified the sense of shared identity between the Reformed congregations in Bohemia-Moravia and Hungary. Since not all the pastors that moved to Bohemia or Moravia in the 1780s stayed abroad and not all of them repatriated, the relationship between the two regions, based on personal experiences and acquaintances, sustained for decades. Participants of the „Bohemian mission“ were not isolated in either country, they did not form separate communities that would severe their ties with their home country and would thus, without exception, lead to assimilation in Bohemia and Moravia. Those who returned to the mother country could be supported by the church district, albeit with great difficulty and hardly at a high level.

Remarkably, in the case of the Reformed population in the church district of Tiszáninnen, aiding the repatriates was closely connected to the process of the institutionalization of the church district and the professionalization of administration. Furthermore, it was certainly a two-way interaction: the organization and the quick success of the „Bohemian mission“ was very important for the history of the internal development of the Reformed Church District of Tiszáninnen as well. 


\section{Appendix}

Chronological owerview: the first registration of the Students (with the last year of presence at Sárospatak in brackets)

1800 Kubesch Mathaeus (1811), Opotsenszki Georgius (1800)

1801 Nespor Josephus (1801)

1802 Flajscher Antonius (1802), Frantzantz Venceslaus (1802), Zajitz Georgius (1802) 1803 Kis Beniamin (1803)

1805 Végh Josephus (1809)

1806 Tardi Gerschon (1810)

1807 Rimany Josephus (1810), Schedivi Josephus (1810)

1808 Fazekas Georgius (1810)

1809 Toronyay Josephus (1813)

1810 Iirista Josephus (1816), Janota Joannes (1814)

1811 Stepanyek Georgius (1816)

1812 Fleischer Josephus (1818), Zajtz Joannes (1818)

1814 Marton Michael (1817), Perklich Antonius (1816), Vidrál Franciscus (1822)

1815 Fleischer Carolus (1827)

1816 Bory Stephanus (1824), Szvoboda Joannes (1822)

1819 Filippi Franciscus (1822)

1820 Esztenák Josephus (1824)

1821 Neszed Josephus (1822)

1824 Gacser Josephus (1824), Kazay Johannes (1832), Kosúth Antonius (1826), Ro-

mesch Stephanus (1824), Tardy Stephanus (1833), Toms Venzeslaus (1831)

1825 Gál Franciscus (1826), Gáspár Joannes (1828), Jelen Joannes (1830), Mikuletzky?

(1829), Tardy Moses (1827)

1826 Holli Paulus (1828), Kral Franciscus (1835)

1827 Jaron Vintentius (1827)

1828 Holly Josephus (1833), Repa Joannes (1831), Totusek Josephus (1832)

1829 Nyitzek Andreas (1833), Urbanek Josephus (1829)

1832 Schollin Johannes (1837)

1833 Karla Johannes (1833), Schlachta Josephus (1836)

1834 Serák Franciscus (1843)

1835 Fikkel Samuel (1836), Kiss Ludovicus (1836)

1836 Hohneh Josephus (1843), Opotsenszky Josephus (1837)

1840 Veherták Franciscus (1840) 
János Ugrai

\section{Hungarian Consequences of the Toleration Missions to Bohemia and Moravia around 1800}

\section{Abstract}

The help provided by Hungarian fellow believers played a crucial role in the revival of Protestantism in Bohemia and Moravia after the Edict of Toleration of 1781. Two thirds of the approximately 70 reorganized Reformed congregations had Hungarian pastors from Hungary. Most of them had been sent by the Reformed Church District of Tiszáninnen, which convinced almost 40 young preachers to participate in the „Bohemian mission.“ Whereas the missionary work of the pastors in Bohemia and Moravia has been amply researched, the impact of their missions on Hungary has been largely neglected. Their mission was, however, a relationship with two ends. In this article I seek to close this gap on the basis of recently collected data on students from the Bohemian lands at the Reformed College of Sárospatak and the documents on the repatriation of the Toleration Preachers and their widows who returned back to Hungary.

KEYWORDS:

Czech History; Hungarian History; Protestantism; Toleration Preachers; Reformed College of Sárospatak; repatriation. 